\title{
Amino acid analysis of pre-Holocene foraminifera from Kriegers Flak in the Baltic Sea
}

\author{
Ole Bennike and Bernd Wagner
}

The Geological Survey of Denmark and Greenland (GEUS) and the Institute of Baltic Sea Research in Warnemünde (formerly the Institut für Meereskunde of the DDR) have co-operated for more than two decades on unravelling the history of the south-western part of the Baltic Sea, mainly based on shallow seismic profiling, sampling of sediment cores and analyses of core samples (Jensen et al. 2002). Here we report on some results from one of the latest joint cruises with the German research vessel Maria S. Merian.

The Baltic Sea is one of the largest brackish-water seas in the world. However, during wide periods of the Quaternary, the Baltic Sea area was either covered by the Scandinavian ice sheet, or was a lake or a land area. Well-dated marine deposits are only known from the last interglacial stage (the Eemian) and from the Holocene. During the Eemian, connections to the Baltic Sea were found via Karelia to the White Sea, and via Denmark and northern Germany to the North Sea (Funder et al. 2002). During the Holocene, a connection to the North Sea was first established during the Yoldia Sea stage via south-central Sweden, and later during the Littorina Sea stage via the Danish/German/Swedish straits (Björck 1995).

In addition to Holocene and Eemian deposits, preHolocene marine sequences from Germany, Poland, Estonia and Latvia have been referred to the Holsteinian, the Saalian and the Weichselian (e.g. Kalnina 2001). In Poland seven marine sequences of Weichselian ages were reported by Gałąazka \& Marks (2009). However, the chronology and correlation of these deposits are uncertain.

During regional mapping in the early 1990s, the Geological Survey of Sweden discovered pre-Holocene marine sediments to the north-east of Kriegers Flak in the western part of the Arkona Basin (Fig. 1A). This find has major palaeogeographical implications because it is the only interstadial marine deposit reported from the area. The occurrence was described by Klingberg (1998). However, the age of the deposit was uncertain, with the only hint coming from a nonfinite radiocarbon age determination which showed that the deposit is older than $40000{ }^{14} \mathrm{C}$ years (lab. no. Ua-4116). Recently, five samples from non-marine sediments deposited above the brackish unit at Kriegers Flak, but in connection with it, have been radiocarbon dated - and gave finite ages
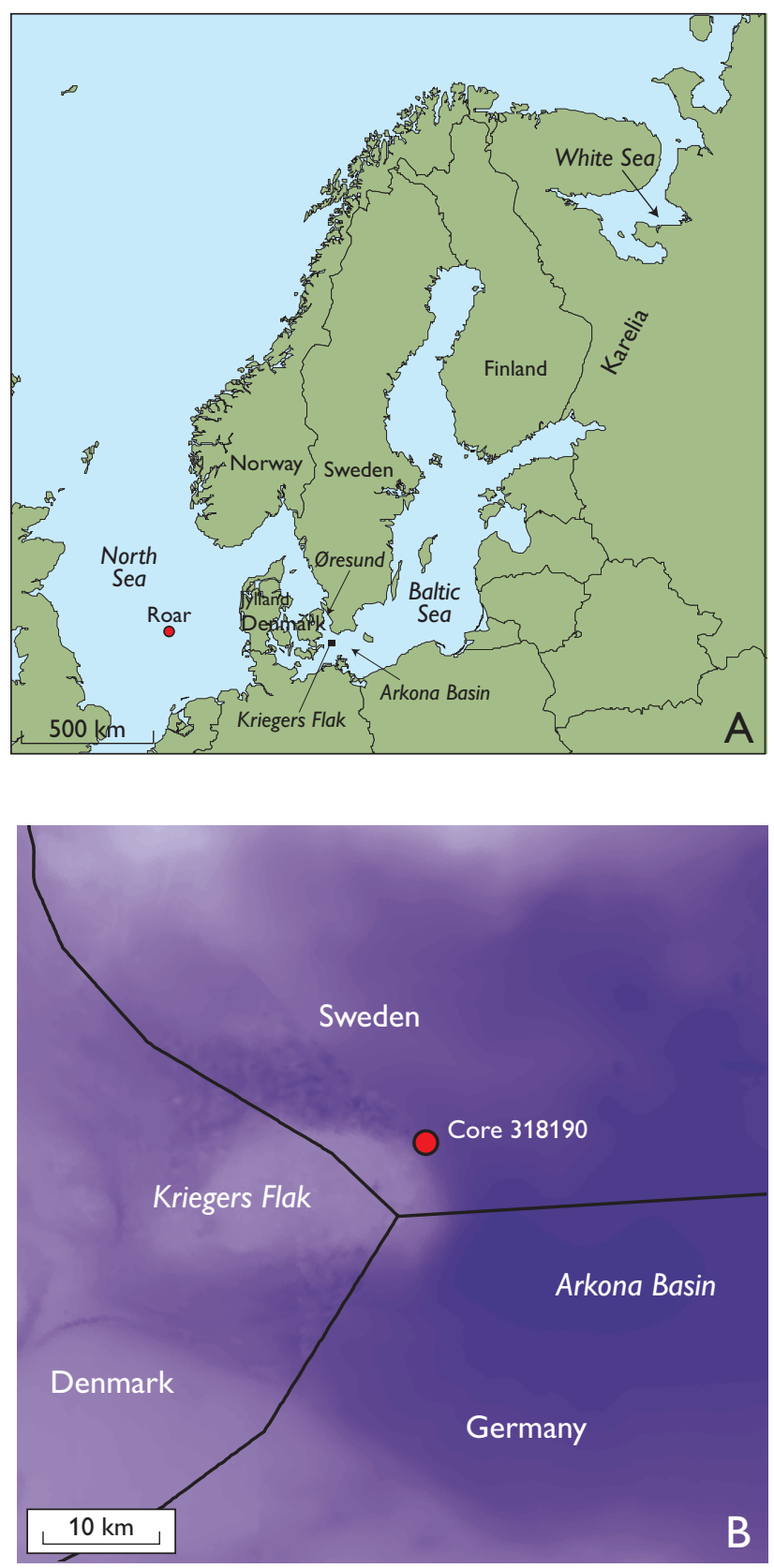

Fig. 1. A: Map of north-western Europe showing the location of Kriegers Flak and the location of place names mentioned in this paper. B: Bathymetrical map of the Kriegers Flak area, showing the location of the studied core. The water depth varies from $c .15 \mathrm{~m}$ (the lightest areas) to $c .45 \mathrm{~m}$ (the darkest areas). 
of c. 36000 - 41000 calendar years BP, indicating a Middle Weichselian age (Anjar et al. 2010).

Klingberg (1998) noted that the sequence consists of stiff clay underlain and overlain by till. Part of the marine clay contains species-poor foraminiferal faunas dominated by Elphidium excavatum and Elphidium albiumbilicatum. The fauna implies brackish-water conditions, which was confirmed by extremely low $\delta^{18} \mathrm{O}$ values of carbonate from the foraminifera tests at between -11.2 and $-11.9 \%$ (Klingberg 1998). Ordinary sea water and carbonates precipitated from it have values close to zero, whereas the Greenland ice sheet ranges between -32 and $-44 \%$ (North Greenland Ice Core Project members 2004). A reasonable way to explain the low values from Kriegers Flak is by assuming a mixture of sea water and meltwater from the Scandinavian ice sheet. Five samples from the clay were analysed for pollen, but the interpretation of the pollen spectra was hampered by the presence of reworked pollen grains (Klingberg 1998).

In order better to constrain the age of the deposit, new material was collected and a sample of foraminifera tests analysed for the ratio between L-isoleucine and D-alloisoleucine. Since its development in the late 1960s, amino acid geochronology has been increasingly used for dating and correlating late Cenozoic deposits that are beyond the range of radiocarbon dating (Miller \& Brigham-Grette 1989). Most studies are performed on mollusc shells and tests of foraminifera. Protein in live organisms consists of amino acid molecules in the L-isomer form. After the death of the organism, some of the amino acid molecules change to the $\mathrm{D}$-form until an equilibrium is reached. The $\mathrm{D} / \mathrm{L}$ ratio depends on the time elapsed since the death of the organism, the diagenetic temperature history and the species analysed. If the temperature history of a fossil sample is known, it is possible to calculate its age. This, however, is very difficult for the Late Quaternary which is known for its large and rapid temperature shifts. Yet, sites with similar diagenetic temperature histories may be correlated even if that history is unknown. We suggest that deposits in the southern Baltic have experienced approximately similar temperature histories as those in the North Sea and will compare with sites of known age there. We do not consider onshore deposits because these may have experienced different diagenetic temperature histories.

The pioneering study on amino acid geochronology in North-West Europe by Miller \& Mangerud (1985) used mollusc shells from onshore marine interglacial deposits. Following a pilot study by Sejrup et al. (1984), amino acid stratigraphy using foraminiferal tests has been widely used for dating and correlating interglacial marine sequences in the North Sea region (e.g. Knudsen \& Sejrup 1988; Sejrup \& Knudsen 1993, 1999).

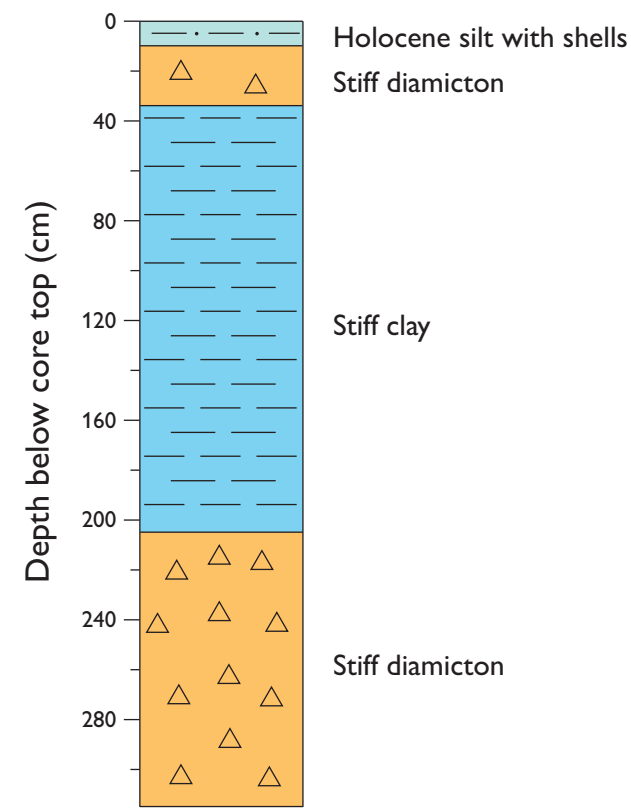

Fig. 2. Lithological log of the sediment core.

In the present study, amino acid analysis was carried out to obtain more information about the age of the deposits from Kriegers Flak. For this purpose, we used tests of the foraminifera Elphidium excavatum as this species has already been widely used in other studies of amino acid ratios in the region. Assuming that Kriegers Flak has experienced a similar temperature history as Denmark and the North Sea, we only compare the $\mathrm{D} / \mathrm{L}$ ratio of Elphidium excavatum with $\mathrm{D} / \mathrm{L}$ ratios from the same species, in order to avoid taxonomical effects which can be significant (e.g. Miller \& Mangerud 1985).

\section{Material and methods}

Vibro-coring was carried out in the north-eastern Swedish part of Kriegers Flak, at the position $55^{\circ} 04.08^{\prime} \mathrm{N}$, $13^{\circ} 11.63^{\prime} \mathrm{W}$, at a water depth of $39.7 \mathrm{~m}$ (Fig. 1B). A $6 \mathrm{~m}$ long corer was used, but it only penetrated $315 \mathrm{~cm}$. The core (no. 318190, Institute of Baltic Sea Research) consisted of diamicton $(315-205 \mathrm{~cm})$, light, olive-grey, stiff clay $(205-34 \mathrm{~cm})$, diamicton $(34-10 \mathrm{~cm})$ and silt with shells of marine molluscs $(10-0 \mathrm{~cm}$; Fig. 2). A series of samples from the clay unit was dried and wet sieved on $0.4,0.2$ and $0.1 \mathrm{~mm}$ sieves. Most of the samples were barren or only contained rare foraminifera, but one of the samples (from 198-193 cm core depth) contained abundant tests of the benthic foraminifera Elphidium excavatum. The foraminifera tests were picked out and split into two subsamples, each weighing around $6 \mathrm{mg}$. Both subsamples were analysed in the Amino Acid Geochronology Laboratory at the Institute of Arctic and Alpine Research, 
Boulder, Colorado. Three measurements were carried out on each subsample. Peptide-bound amino acids were decomposed in the laboratory by hydrolysis, and the analyses were made with a chromatograph. The ratio of $\mathrm{D}$-alloisoleucine to $\mathrm{L}$-isoleucine $(\mathrm{D} / \mathrm{L})$ is based on the peak height in the total population, i.e. both free and peptide-bound amino acids.

\section{Results}

Subsamples AAL-11579A and B gave D/L ratios of 0.106 \pm 0.000 and $0.106 \pm 0.002$, respectively. Although most analyses of foraminifers in North-West Europe have been carried out at the amino acid chronological laboratory at the Geological Institute, Bergen University, we regard the amino acid analyses from the Institute of Arctic and Alpine Research as nearly identical to those from Bergen, since samples processed at both places have yielded similar results (Miller \& Mangerud 1985).

\section{Discussion of age}

Amino acid analyses of numerous samples of Elphidium excavatum tests from various interglacial and interstadial deposits from the North Sea region have been summarised by Sejrup \& Knudsen $(1993,1999)$. In the latter work, the authors divided the North Sea sequence into four amino zones. Zone 1 corresponds to the Holocene and the Late Weichselian, zone 2 includes samples of Eemian age, as well as samples of Late Saalian and Early Weichselian age, zone 3 includes samples of Holsteinian age and zone 4 is correlated with marine isotope stage $11(420-360 \mathrm{ka})$. The $\mathrm{D} / \mathrm{L}$ ratios in amino zone 2 range from 0.08 to 0.12 , and those in amino zone 3 show ratios between 0.14 and 0.16. Subsamples AAL-11579A and $B$ from Kriegers Flak have ratios similar to those of amino zone 2, and thus imply an Eemian, Late Saalian or Early Weichselian age.

Eemian age? An Eemian age for the clay sequence from Kriegers Flak is unlikely, since the foraminiferal faunas consist almost entirely of the two benthic species Elphidium excavatum and Elphidium albiumbilicatum, an assemblage indicating brackish waters in an Arctic/subarctic environment (Klingberg 1998). The fauna is clearly different from Eemian foraminiferal faunas from the region, as they are dominated by species-rich assemblages implying warmer conditions. Elphidium excavatum is common in Late Eemian deposits at Mommark on Als, southern Denmark (e.g. Kristensen \& Knudsen 2006). However, the Eemian deposits at this site show normal marine oxygen isotope ratios, whereas the ratios at Kriegers Flak seem to suggest deposition during a time with extensive melting of glacial ice as noted above.
Early Weichselian age? An Early Weichselian age is also considered unlikely. During the Early Weichselian, the global sea level was lower than at present (e.g. Siddall et al. 2003) and the North Sea as well as the Danish/German/Swedish straits are generally believed to have been dry land (Houmark-Nielsen 1989). According to the glaciation curves of e.g. Lundquist (1986), Houmark-Nielsen (1989) and Mangerud (2004), the Scandinavian ice sheet did not advance to the south-western Baltic during the Early Weichselian. Hence, Arctic/subarctic brackish-water conditions with marked meltwater influence would not be expected in the Kriegers Flak region during this time interval.

Late Saalian age? During the Late Saalian, the sea transgressed large parts of the North Sea and reached as far south as the Roar, where boreo-Arctic and Arctic conditions were found (Fig. 1A; Knudsen 1986). In northern Denmark, the Børglum chronozone of Lykke-Andersen \& Knudsen (1991) reflects interstadial conditions of Late Saalian age. Deposits from an Arctic sea have also been recorded in southern Sweden (Påsse et al. 1988). According to the reconstruction by Houmark-Nielsen (1989), the margin of the Scandinavian ice sheet retreated from the south-western Baltic Sea. We consider it possible that the Øresund region was isostatically depressed following the extensive Late Saalian glaciation and transgressed by the sea for a short time interval after recession of the ice. Brackish waters may have extended to the south-western part of the Baltic Sea, including Kriegers Flak.

Middle Weichselian age? A Late Saalian age is obviously not in accordance with the radiocarbon dates reported by Anjar et al. (2010). The radiocarbon dates are close to the limit of radiocarbon dating and it could be argued that they are unreliable, in particular because four of them were made on bulk sediment samples. Dating of bulk sediment samples commonly yields erroneous results, but usually dates of bulk samples are too old - not too young. Also, all five age determinations gave finite dates, which is a good indication that they are reliable.

We find it difficult to reconcile a Middle Weichselian age with the amino acid data, which suggest an older age. However, in the past decade it has become more and more obvious that amino acid ratios should be used with caution due to their strong dependency on the temperature histories of the deposits. Hence, a Middle Weichselian age cannot be excluded from the amino acid data.

Figure 3 shows a possible palaeogeographical reconstruction. We suggest that the Øresund region was isostatically depressed and transgressed by the sea for a short time interval after recession of the Scandinavian ice sheet. 


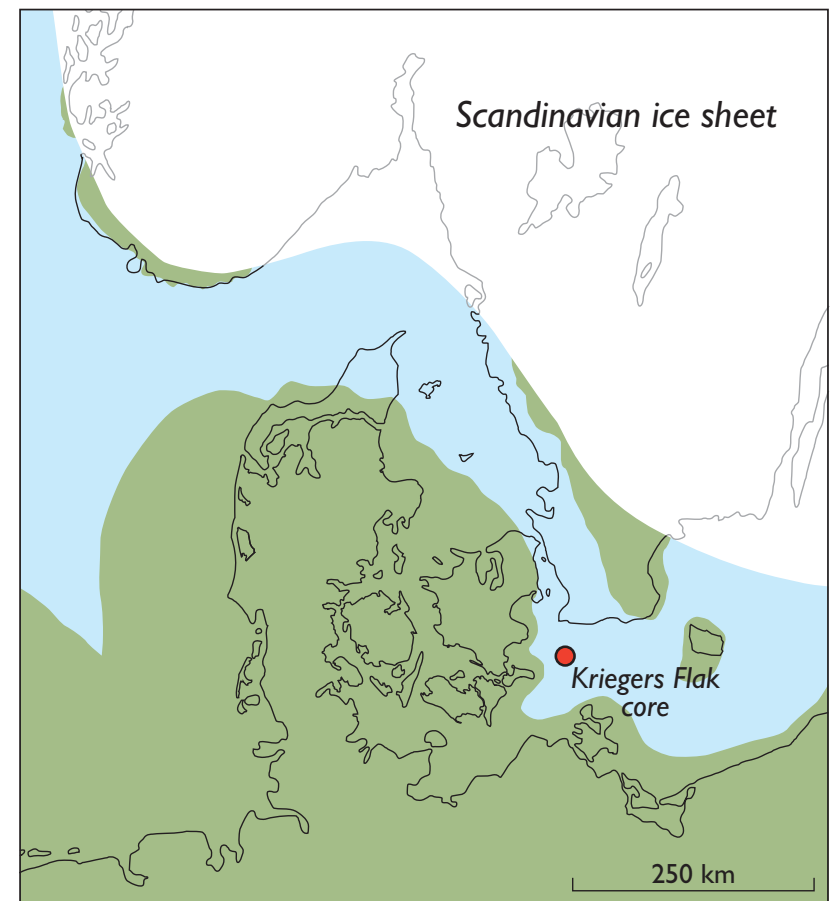

Fig. 3. Palaeogeographical model of southern Scandinavia during deposition of the Kriegers Flak sequence.

\section{Conclusions}

The amino acid ratios from brackish-water deposits on Kriegers Flak suggest a Late Quaternary age, either Late Saalian, Eemian or Early Weichselian. A strong $\delta^{18} \mathrm{O}$ meltwater signal and the foraminiferal assemblage are not compatible with an Eemian age. An Early Weichselian age is also considered unlikely because the sea level was probably too low at this time to allow the sea to transgress the Baltic Sea, and because the margin of the Scandinavian ice sheet was too far away to give a strong meltwater signal. The last option, a Late Saalian age, does not agree with a Middle Weichselian age of the fresh-water deposits that are connected to the brackish-water deposits. Hopefully, other dating methods can be applied at Kriegers Flak in the future to better constrain the age of the sequence.

\section{References}

Anjar, J., Larsen, N.K., Björck, S., Adrielsson, L. \& Filipsson, H.L. 2010: MIS 3 marine and lacustrine sediments at Kriegers Flak, southwestern Baltic Sea. Boreas 39, 360-366.
Björck, S. 1995: A review of the history of the Baltic Sea, 13-8 ka BP. Quaternary International 27, 19-40.

Funder, S., Demidov, I. \& Yelovicheva, Y. 2002: Hydrography and mollusc faunas of the Baltic and the White Sea - North Sea seaway in the Eemian. Palaeogeography, Palaeoclimatology, Palaeoecology 184, 275-304.

Gałąazka, D. \& Marks, L. 2009: Geology of the Lower Vistula region, northern Poland. Polish Geological Institute, Special Papers 25, 13-20.

Houmark-Nielsen, M. 1989: The last interglacial-glacial cycle in Denmark. Quaternary International 3/4, 31-39.

Jensen, J.B., Kuijpers, A., Bennike, O. \& Lemke, W. 2002: BALKAT. The Baltic without frontiers. Geologi - Nyt fra GEUS 4, 19 pp. Copenhagen: Geological Survey of Denmark and Greenland.

Kalnina, L. 2001: Middle and Late Pleistocene environmental changes recorded in the Latvian part of the Baltic Sea basin. Quaternaria A9, $173 \mathrm{pp}$.

Klingberg, F. 1998: A Late Pleistocene marine clay succession at Kriegers Flak, westernmost Baltic, southern Scandinavia. Journal of Quaternary Science 13, 245-253.

Knudsen, K.L. 1986: Middle and Late Quaternary foraminiferal stratigraphy in the southern and central North Sea area. Striae 24, 201-205.

Knudsen, K.L. \& Sejrup, H.P. 1988: Amino acid geochronology of selected interglacial sites in the North Sea area. Boreas 17, 347-354.

Kristensen, P.H. \& Knudsen, K.L. 2006: Palaeoenvironments of a complete Eemian sequence at Mommark, south Denmark: foraminifera, ostracods and stable isotopes. Boreas 35, 349-366.

Lundquist, J. 1986: Stratigraphy of the central area of the Scandinavian glaciation. Quaternary Science Reviews 5, 251-268.

Lykke-Andersen, A.L. \& Knudsen, K.L. 1991: Saalian, Eemian and Weichselian in the Vendsyssel-Kattegat region, Denmark. Striae 34, 135-140.

Mangerud, J. 2004: Ice sheet limits on Norway and the Norwegian continental shelf. In: Ehlers, J. \& Gibbard, P. (eds): Quaternary glaciations - extent and chronology 1, 271-294. Amsterdam: Elsevier.

Miller, G.H. \& Brigham-Grette, J. 1989: Amino acid geochronology: resolution and precision in carbonate fossils. Quaternary International $\mathbf{1}$, 111-128.

Miller, G.H. \& Mangerud, J. 1985: Aminostratigraphy of European marine interglacial deposits. Quaternary Science Reviews 4, 215-278.

North Greenland Ice Core Project members 2004: High-resolution record of northern hemisphere climate extending into the last interglacial period. Nature 431, 147-151.

Påsse, P., Robertsson, A.-M., Miller, U. \& Klingberg, F. 1988: A Late Pleistocene sequence at Margreteberg, southwestern Sweden. Boreas 17, 141-163.

Sejrup, H.P. \& Knudsen, K.L. 1993: Paleoenvironments and correlations of interglacial sediments in the North Sea. Boreas 22, 223-235.

Sejrup, H.P. \& Knudsen, K.L. 1999: Geochronology and palaeoenvironment of marine Quaternary deposits in Denmark: new evidence from northern Jutland. Geological Magazine 136, 561-578.

Sejrup, H.P., Rokoengen, K. \& Miller, G.H. 1984: Isoleucine epimerization in Quaternary benthonic foraminifera from the Norwegian continental shelf: a pilot study. Marine Geology 56, 227-239.

Siddall, M., Rohling, E.J., Almogi-Laban, A., Hemleben, C., Meiscner, D., Schmelzer, I. \& Smeed, D.A. 2003: Sea-level fluctuations during the last glacial cycle. Nature 423, 853-858.

\section{Authors' addresses}

O.B., Geological Survey of Denmark and Greenland, Øster Voldgade 10,DK-1350 Copenhagen K, Denmark. E-mail: obe@geus.dk B.W., Baltic Sea Research Institute, Seestrasse 15, D-18119 Rostock-Warnemünde, Germany. Present address: Institute for Geology and Mineralogy, University of Cologne, Zülpicher Str. 49a, D-50674 Cologne, Germany. 